Article

\title{
Which Human Resources Are Important for Turning Agritourism Potential into Reality? SWOT Analysis in Rural Nepal
}

\author{
Kumar Bhatta ${ }^{1, *}$, Yasuo Ohe ${ }^{2}$ and Adriano Ciani ${ }^{3,+}$ \\ 1 Department of Food and Resource Economics, Chiba University, Chiba 271-8510, Japan \\ 2 Department of Agribusiness Management, Tokyo University of Agriculture, Tokyo 156-8502, \\ Japan; yo207358@nodai.ac.jp \\ 3 World Friendship Association of Rural Areas (AMAR-WFARA), 06125 Perugia, Italy \\ * Correspondence: kumar2bhatta@chiba-u.jp; Tel.: +81-70-3528-0600 \\ + Passed away at the end of April, 2020.
}

Received: 13 April 2020; Accepted: 23 May 2020; Published: 1 June 2020

\begin{abstract}
Despite Nepal's agritourism strategies for promoting agrarian villages, agritourism has not yet gained popularity. Based on two different surveys conducted in August 2017 and January 2019, we explore the agritourism development strategies and the agritourism potential for Phikuri village, an agrarian village in Nepal. Using a strengths, weaknesses, opportunities, and threats (SWOT) matrix, we explore four main strategies and 15 sub-strategies. The four main categories are as follows. A maxi-maxi strategy characterised by strengths and opportunities, a maxi-mini strategy characterised by strengths and threats, a mini-maxi strategy characterised by weaknesses and opportunities, and a mini-mini strategy characterised by threats and weaknesses. A quantified SWOT matrix of the estimated total value of the internal and external factor evaluation matrices reveals that Phikuri village has more strengths than weaknesses and more opportunities than threats. We statistically compare the opinions of three different groups, organised by gender, age, and occupation. The results reveal statistically significant differences in the opinions of men and women, younger and older generations, and public and private workers. This study also shows that women are critical for agritourism development, even in a male-dominated society.
\end{abstract}

Keywords: agritourism; developing country; human resources; role of women; SWOT strategies; Nepal

\section{Introduction}

Agritourism in developing economies has been receiving increasing attention, although it is still in its development phase [1-3]. A sustainable agritourism development process requires investigating the agritourism potential, exploring development approaches and strategies, and assessing human resources. In general, the word "strategy" refers to the broad collection of decisions, rules, and procedures required to implement a specific project [4]. In this study, agritourism development strategies refer to the guidelines used to establish sustainable agritourism in an agrarian village. Due to the scarcity of literature on the subject, especially the scarcity of studies focused on developing economies, it is difficult to find agritourism development guidelines for agrarian villages. It is also difficult to determine which human resources are suitable in this context.

There are a modest number of studies that explore the strategies and human resources necessary for agritourism development in developed economies. For example, Kuehn et al. [5] present strategies for the evaluation and planning of the stages involved in establishing or expanding agritourism in the United States. George and Rilla [6] focus on marketing strategies, whereas Roth and Ochterski [7] 
show how to begin agritourism operations. However, both studies offer only general ideas rather than specific scenarios.

Further, Telfer [8] explores the alliance strategies that exist between agriculture and tourism in Niagara, Canada. Embacher [9] examines the strategy and practices of a highly developed tourist destination in Austria. Carra et al. [10] present a study on the Etna wine route in Sicily, Italy. Similarly, the Indiana State Department of Agriculture [11] defines the planning process and possible obstacles of agritourism in Indiana. Regarding the human resources required for agritourism, studies on developed economies state that women generally have a more crucial role in agritourism [3,12-15], whereas men generate more income and profit from the industry [16]. However, the roles of women in agritourism in developing economies are still not clearly known because of limited research.

Nevertheless, the studies above are mostly focused on industrial economies, or more precisely, on established tourism destinations. In comparison, the capabilities of tourism operators in developing economies are markedly different because of factors such as the economic background, the levels of education, infrastructure, and the level of organisation in tourism destinations. Thus, we cannot generalise the findings of such studies.

Regarding tourism development strategies, studies have been known to use the strengths, weaknesses, opportunities, and threats (SWOT) analysis to investigate a destination's potential and explore different agritourism strategies. With this approach, the intent is to maximise a destination's strengths and opportunities, while minimising its weaknesses and threats. Such examples include the sustainable tourism strategies for Bangladesh [17] and an Iranian national park [18], as well as the use of a quantified SWOT approach to transform the Black Sea region of Turkey into a tourist destination [19].

Although efficient strategies are essential for sustainable agritourism development, no study has attempted to investigate this area. We believe that a SWOT analysis helps in assessing a destination's agritourism development potential, as well as the strategies needed to succeed. It also helps in selecting the best strategy [20] by maximising the strengths and opportunities, as well as by reducing the weaknesses and threats [17]. The SWOT analysis is not only useful to developed tourism destinations, but it is also useful to villages (agrarian villages where tourism activities are not common) with the potential for agritourism development, and thus, the need for appropriate strategy development.

Many studies on developing economies that focus on agritourism development, most of which use the SWOT analysis [2,21,22], consider only the potential of agritourism. For example, a study on strategies [23] for the expansion of wine tourism in an already-developed tourism destination failed to deal with human resources. Agritourism development in agrarian villages could uplift the economic conditions of farmers and alleviate poverty through the generation of extra income. As a result, these regions could develop more diverse and sustainable rural economies [24]. As per our knowledge, no study has employed the SWOT analysis to assess agritourism development strategies for destinations in which agritourism has not yet been initiated.

In this study, two different surveys were conducted in rural Nepal. The first survey was conducted using a questionnaire involving 64 farmers as respondents. The data were used to define the possibilities for agritourism development in Phikuri village using the SWOT analysis. The defined SWOT analysis also assessed the conditions of human resources in the village. The second survey was conducted with 22 experts as respondents who evaluated the defined SWOT analysis and tested the hypotheses.

We chose Nepal as our study location because it is a developing country. Moreover, the Nepalese government has been trying to identify new tourism destinations to expand the industry in different rural areas [25]. Further, Bhatta et al. [1], Bhatta, and Ohe [26] established that farmers in rural Nepal are willing to be involved in agritourism. However, these studies did not consider the strategies and human resources that are required for agritourism development in agrarian villages. Investigating the roles of women in agritourism is also particularly essential for both developing and developed economies because female labour in households is far less common than male labour, although it also contributes to agriculture. Thus, this study aims to: 
- Investigate the potential for agritourism development in rural Nepal;

- Explore the strategies necessary for agritourism development in an agrarian village;

- Investigate the roles of women in relation to human resources in agritourism.

Based on the results, we present the implications for agritourism development.

\section{Literature Review}

\subsection{Defining Agritourism}

Rural tourism evolved and became popular in the 1970s in Europe [27]. Later, the concept of agritourism emerged in Europe and other developed countries [28,29]. Previous research did not study rural tourism and agritourism in developing economies. In many countries, terms such as agritourism and rural tourism were used interchangeably over the years [30,31]. In recent years, however, many scholars have been debating on each definition, and, in response, offered new definitions [32]. Consequently, the term agritourism is now defined differently in different countries (Table 1).

Table 1. Agritourism definition in different countries.

\begin{tabular}{cl}
\hline Country & Definition of Agritourism \\
\hline Hungary & $\begin{array}{l}\text { The term village tourism involves affordable accommodation and implies engaging } \\
\text { in agricultural activities or other types of local activities. }\end{array}$ \\
\hline Slovenia & $\begin{array}{l}\text { Rural tourism is farm tourism. During a farm visit or while having meals in farms, } \\
\text { tourists have the choice of living either in a guest house or in a farmhouse. }\end{array}$ \\
\hline The Netherlands & $\begin{array}{l}\text { Route-related services are provided to tourists, such as cycling, horse riding, and } \\
\text { walking. Tourists also enjoy camping on farms. }\end{array}$ \\
\hline Greece & $\begin{array}{l}\text { Tourists can enjoy their stay on farms that offer bed and breakfast. Rooms are } \\
\text { furnished with traditional furniture and breakfast includes homemade dishes. }\end{array}$ \\
\hline Italy & $\begin{array}{l}\text { Agritourism refers to activities of hospitality performed by agricultural } \\
\text { entrepreneurs and their family members that must remain connected and } \\
\text { complementary to farming activities. }\end{array}$ \\
\hline Japan & $\begin{array}{l}\text { Green tourism offers accommodation and other services such as meals, and farm } \\
\text { and rural experience services while taking advantage of tangible and intangible } \\
\text { rural assets such as rural amenities, heritage, local food culture, and farm products. } \\
\text { (From 2017 onwards, a new term 'no-haku', meaning farm stays, was used) }\end{array}$ \\
\hline USA & $\begin{array}{l}\text { Agritourism refers to activities that include visiting a working farm or any } \\
\text { agriculture-based operations for leisure purposes, to get educated, or to get } \\
\text { involved in various other activities. }\end{array}$ \\
\hline
\end{tabular}

Source: Several authors [29,32-35].

Agritourism is a type of tourism in which tourists take part in farm and village activities as well as spend time with animals. The hosts also provide services such as cooking, cleaning, handicrafts, and entertainment [28]. Thus, the tourist participates in farm life as an educative experience or for recreational purposes. More specifically, McGehee and Kim [36] classify these actions as agritourism.

Agritourism in the US is characterised by pick-your-own produce farms, animal interactions, and taking part in agrarian festivals. Rural tourism is considered to have a positive effect on rustic areas, natural resources, culture, rural houses, village traditions, and agricultural products [32]. These definitions seem almost similar, and it is difficult to differentiate between them. In this context, Eurac Research [37] proposed a definition of agritourism at the 1st World Congress on Agritourism held in Bolzano, Italy, in 2018. The definition proposed was 'the activities that are performed at farms and hosted by farmers'.

Due to less-mechanised infrastructure and a minimal number of tourism destinations in Nepal, rural tourism could be considered as part of agritourism. As Nepal is a country in the Himalayas and is known for its exquisite and picturesque landscapes, tourists stay in farms, eat farm produce, 
participate in farm activities, and enjoy the rural culture and nature activities, such as hiking, jungle safaris, and bird-watching in the wild.

\subsection{Conditions Necessary for Increasing the Potential of Agritourism}

There are two major perspectives on investigating the potential of agritourism: development and promotion. According to the characteristics related to the development and promotion of agritourism, the human resources and marketing strategies required are very critical for increasing the potential of agritourism. The promotion of agritourism only starts after its development. Hence, we do not focus on the promotion of agritourism.

Agritourism is a comparatively new concept for Nepal because authentic agritourism does not exist in the region [1]. Since a potential assessment of agritourism is the first step for its development, we define our first hypothesis as follows. $\mathrm{H}_{1}$ : Normal agrarian rural villages also hold the potential for agritourism development. Another important issue to be considered in exploring the agritourism potential of Phikuri village is human resources. Although there are many conditions necessary for the establishment of agritourism, we focus more on the role of women as a human workforce in the development of agritourism.

Studies also exist that describe the important role of women in successful agritourism development [12-15]. However, in male-dominated societies, the role of women is often underestimated, and they are often not allowed to work in tourism industries. For example, because of the cultural shame that surrounds working in the tourism industry and the reluctance of women to work outside the home, Iranian women are not allowed to work in hotels [38]. Further research shows that, although Iranian women are often more highly educated than their male counterparts, the former are restricted from working in higher positions that are related to their educational qualifications. This issue exists because of government regulation that prevents hotels from hiring women for senior positions [38]. Similarly, Portuguese women also face gender barriers, even after occupying senior positions in tourism organisations [39]. In Turkey, males decide whether their female spouses can work in the agritourism industry [40,41]. The same barriers exist in Uganda [42].

Outside the Middle East, Europe, and Africa, Anuja and Cooper [43] find that rural areas throughout the Asia-Pacific region are still characterised by a culture that does not allow women to achieve a high economic and social status. Anuja and Cooper [43] further find that rural tourism could change the status of women in India. However, the government should facilitate their roles, both institutionally and systematically.

In Nepal, most regions have male-dominated societies, and men often influence women's decision-making [1]. We believe that the development of agritourism can change women's socioeconomic status in the long run. For example, the active participation of women is found to contribute to successful rural tourism in Japan [3,13]. Similarly, through tourism-based entrepreneurship, local women have attained not only economic but also psychological, social, and political empowerment in Fiji [44]. Thus, we develop the second hypothesis. $\mathrm{H}_{2}$ : The role of women in agritourism is important even in a male-dominated society where women are more involved in household activities.

Although the promotion of agritourism starts after its development, it can be taken as a condition for agritourism success. The promotion of tourism activities in rural areas must be systematic, co-creative, distinctive, and memorable for tourists [45]. The promotional strategies of agritourism in California can be taken as a standard promotional strategy for Nepal as well. These strategies involve understanding the target market; understanding the industry (customers, community relations, offseason offerings, and unique products); knowing the products involved; launching promotional campaigns; evaluating market success; working with neighbours; participating in community activities; and collaborating with local businesses [6].

In Nepal, ecotourism and community-based homestays are already popular in some villages. They are found to have increasing value to rural communities [26]. Such ventures bring considerable 
revenue to the villages and can become a useful foundation for building the agritourism industry. Villages already engaged in ecotourism can readily incorporate agritourism into their activities by offering agricultural experiences to visitors, along with the staple homestays, tea shops, restaurants, and local lodges. Since agritourism is in the development phase in Nepal, this study focusses on exploring the development strategies of agritourism and investigating the role of women in the agritourism workforce.

\subsection{Potential Assessment Methods and SWOT Analysis}

Different scholars use different potential assessment models to explore the potential of tourism in their studies. The geographic information system (GIS) model analyses elements such as the slope, altitude, climate-vegetation, land use, fauna, culture, sports facilities, and the level of infrastructure in an area [46]. For example, the stakeholder assessment model has been used to explore similar potential in Ogimachi, Japan, through the analysis of different stakeholders, contributing to the development of tourism in that location. Evidently, the opinion of local residents was prioritised, as they may not permit the use of their private land and resources for agritourism [47]. Stavros [48] states that the SOAR (strengths, opportunities, aspirations, and results) model is a strength-based framework with a multiple stakeholder approach to strategic thinking. Similarly, the item response or the hierarchical theory was used to rank tourism resources and attributes based on the potential of tourism development in a Spanish location [49]. The demand-side analysis was used to explore the destination attractiveness as well as the facilities available in Thailand [50].

The SWOT analysis is a widely accepted model that is used to investigate the strengths, weaknesses, opportunities, and threats of a business or project and can be used for strategy development [51]. For most strategic planners, it is the first stage of a long planning process [48]. In the initial stages of agritourism development, we not only assess the potential of agritourism, but also develop the strategies that are necessary for agritourism development in Nepal. Hence, we believe that the SWOT analysis is suitable in this study.

A SWOT or TOWS analysis is a system of methods that analyse internal strengths and weaknesses as well as external opportunities and threats [17]. In the SWOT analysis, ' $\mathrm{S}$ ' and ' $\mathrm{O}$ ' stand for positive factors, while ' $W$ ' and ' $T$ ' are negative factors for a particular destination, business, or project $[10,23,52]$. Overall, a SWOT analysis can study and compare the internal and external environments of a product, destination, or industry. In the field of tourism, SWOT strategies are mostly used to develop strategies in relation to a destination. According to Goranczewski and Puciato [53], the SWOT analysis is the most popular method of strategic analysis in the Polish economy. Generalising this method, we use the SWOT analysis in agritourism to answer the following questions:

SO: How can farmers discover their strengths and take maximum advantage of their opportunities? ST: How can rural areas take advantage of their strengths to avoid real and potential threats?

WO: How can farmers use their opportunities to overcome the weaknesses that they have?

WT: How can the farmers minimise their weaknesses and avoid threats?

Considering that all the factors in a SWOT analysis are challenging, those factors that are of prime importance and are critical in determining the future should be the focus, and less essential elements should be avoided [53]. The location of agritourism always tries to increase its strengths, and it seeks opportunities. It seeks to minimise industrial weaknesses and tackle external threats [52]. Thus, SWOT analysis strategies can be developed accordingly. The SWOT strategic planning model is a method of decision-making, that selects short- or long-term strategies, and makes significant and critical decisions about various problems [54].

SWOT strategies can be developed by combining internal factors with external factors [10]. For agritourism development in a village, as mentioned earlier, strengths and opportunities are positive factors in relation to the location, whereas weaknesses and threats are negative factors. In this study, we define the SWOT analysis by analysing the internal environment and the external environment 
from both a positive and negative perspective. Based on the above definitions, we derive four different strategies. By combining strengths and opportunities, we derive a maxi-maxi or an attack strategy; by combining strengths and threats, we derive a maxi-mini or a defence strategy; by combining weaknesses and opportunities, we derive a mini-maxi or an adaptation strategy; and by combining weaknesses and threats, we derive a mini-mini or crisis strategy.

Besides the SWOT strategies, Goranczewski and Puciato [53] recommend using the probability of strategic success (PSS) to choose a suitable strategy for a business. PSS involves the calculation of the standard critical internal and external factors to determine whether there are more strengths than weaknesses and more opportunities than threats in the destination [53]. Based on the results of PSS, proper strategies can be selected for agritourism development in a destination.

Reihanian et al. [18] and Mondal [17] employ the internal factor evaluation matrix (IFEM) and external factor evaluation matrix (EFEM) to investigate the internal and external environments to select the best strategy for sustainable tourism development in Iran and Bangladesh. We also adopt their methods to explore tourism strategies in Phikuri village in Nepal.

\subsection{Nepalese Economy and Tourism}

Nepal is a developing country, and agriculture is very crucial to its GDP. As per the data of the Ministry of Finance [55], around 65\% of the population engages in agriculture, and agriculture contributes to less than one-third of the national GDP. About $20 \%$ of its population is poor [55]. Nepal suffers from low productivity and massive underemployment and has a great dependence on subsistence farming. According to available data, agricultural output is not satisfactory, and farming income should be increased.

In 2015, Nepal's new constitution came into effect after being endorsed by its constituent assembly. As per the mandates of the constitution, the Nepalese administrative division was restructured and went from being a kingdom to being a federal system. By the end of 2017, an election for all three tiers of government (federal, state, and local) was successfully conducted. All three tiers of government have attained stable governance since their inception in 2017.

Because of the above political transformation, the Nepalese economy has witnessed positive and steady growth. The economy grew by $7.9 \%$ and $6.3 \%$ in 2017 and 2018, respectively [56]. As a result, tourism has also boomed over the last decade. The number of tourists reached a new record of 1.17 million in 2018 [57]. The Nepalese government and the Ministry of Tourism and Civil Aviation, together with industry partners, established the Nepal Tourism Vision 2020 to increase the annual number of tourists visiting the country. To host two million tourists in 2020 and increase economic opportunities and the level of employment in the tourism sector to one million employed, the government declared the Visit Nepal 2020 strategy [25]. The government is also trying to explore new tourism destinations. The policy framework mentioned above can serve as an opportunity for agritourism development in Nepal.

\section{Methods}

\subsection{Study Area}

We selected Phikuri village in Nepal as the study area because it is an agrarian rural village in a good location (it is near a highway, and it is also near the capital city, and the Chinese border is just $110 \mathrm{~km}$ away) and it has plenty of untapped tourism potential (the corresponding author of this study was born and raised in the village, which facilitated ease of access). The Nepal Government Census [58] reports that the village has four major ethnic communities living in 636 households. However, the 2015 earthquake completely destroyed many houses. Thus, new houses have been built in the village. These houses can also be used for agritourism. 


\subsection{Data}

Two different surveys were conducted for this study. The first questionnaire survey was conducted in August 2017 with farmers as respondents. A questionnaire set was used, and 64 samples from the first survey were collected to assess the quantitative data. We believe that the data are representative of the ethnic groups and location. For qualitative information, we conducted formal group discussions, informal conversations, and field observations. Table 2 reports the respondents' attributes from the first survey. We define the SWOT of agritourism in Phikuri village based on the data of the first survey.

In January 2019, the second survey was conducted with experts from the village who now work in prestigious national and international organisations. With the help of the experts, we conducted the second survey to verify the SWOT defined earlier. Initially, the names of the experts were obtained with the help of the villagers. The criteria for the selection of the experts were: university education; over three years of employment (government, private, or self-employed); and born and/or raised in Phikuri village or residing in Phikuri village for over three years. These criteria were set to assure that all the respondents were familiar with the current situation of the village and were responsible for tourism development in their village. The study excluded those people whose permanent address officially changed, even if they met the criteria and had family members still residing in the village. The prospective experts (a total of 27) were contacted via email, and 22 of them accepted our proposal. All questions were developed on a five-point Likert scale designed using Google Forms and sent to the experts. The study covered different fields of expertise. The experts were categorised into seven fields: professors/teachers $=4$, government officers $=4$, businesspeople $=2$, politicians $=2$, working in foreign countries $=4$, tourism-related work $=3$, others $=3$. The respondents were between 22 and 45 years of age. Among them, $59.1 \%$ were university graduates, $31.8 \%$ were master's degree graduates, and $9.1 \%$ were $\mathrm{PhD}$ degree holders. The farmers were not included in the second survey because their opinions were extracted from the first survey.

Table 2. Attributes of the farmers.

\begin{tabular}{ll}
\hline Variables & Contribution \% (Frequencies) \\
\hline Respondents & Male $=71.9(46)$, Female $=28.1(18)$ \\
At least one person from the family abroad (>1 year) & Yes $=45.3(29)$, No $=54.7(35)$ \\
Interested in a new job(s) & Yes $=89.1(57)$, No $=11.9(7)$ \\
Member of community groups & Yes $=79.7(51)$, No $=20.3(13)$ \\
Educational background $※$ & $\leq 10$ years schooling $=85.9(287)$ \\
& $\geq 10$ years schooling $=14.1(47)$ \\
Normal English communication $※$ & Yes $=62.3(208)$, No $=37.7(126)$ \\
At least one person working in the tourism sector & Yes $=87.5(56)$, No $=12.5(8)$ \\
Types of work in tourism & Trekking guide $=5.4(3)$, Tour $=5.4(3)$, \\
& Trekking porter $=89.3(50)$ \\
\hline
\end{tabular}

Source: Authors' survey of the farmers, August 2017. Notes: Sample size is $64, ※$ is the total sample size (334). The family members of the respondents are also included in this figure. The sample size is in parenthesis.

\subsection{Analytical Methods}

\subsubsection{The IEFM and EFEM Matrix}

Based on the data from the first survey in August 2017 and the second survey in January 2019, in defining the SWOT, we apply the statistical tests. Integrating the information gathered from the first and second surveys, we generate the IFEM and the EFEM to compare the factors affecting agritourism in the Phikuri village. This model helps us test $\mathrm{H}_{1}$ (normal agrarian rural villages also hold the potential for agritourism development).

We adopt the SWOT model used by Reihanian et al. [18] and Mondal [17] for the IFEM and EFEM. The step-by-step process of IFEM and EFEM analyses are as follows: 
1. Each internal strength and weakness is assigned a weight (Wt.) ranging from 0.00 (low significance) to 1.00 (high significance). More significant factors are assigned a higher weight and vice versa. Note that the total weight of all internal factors should be 1.00.

2. Each factor is assigned an effective score (E) ranging from 1 to 4 . The scores are assigned based on whether the factor represented a major weakness $=1$, minor weakness $=2$, minor strength $=3$, and major strength $=4$. The average responses of the second survey are employed to decide if the factors are major or minor (average score of $\geq 3.0=$ major and $\leq 2.99=$ minor).

3. The weight (Wt.) and the effective score (E) are multiplied to arrive at a weighted score for each factor, and this score is added to get the total weighted score (F) of the IFEM.

4. If the total value of $\mathrm{F}$ is $\leq 2.5$, then there are fewer strengths than weaknesses; if $\mathrm{F}$ is $\geq 2.5$, then there are more strengths than weaknesses.

5. The same process is repeated to determine the total weighted score of the EFEM. The rating of the EFEM includes minor threats $=1$, major threats $=2$, minor opportunities $=3$, and major opportunities $=4$. The same measurement process of the IEFM is employed to judge if the factors are major or minor. If $\mathrm{F}$ of the EFEM is $\leq 2.5$, then there are fewer threats than opportunities; if $\mathrm{F}$ is $\geq 2.5$, then there are more opportunities than threats [18].

\subsubsection{The PSS Calculation}

SWOT scoring can also be used to determine the PSS [53]. We follow the model presented by Goranczewski and Puciato [53] to examine the SWOT of agritourism in Phikuri village. This model comprises the following steps: strengths $(\mathrm{S})$, weaknesses $(\mathrm{W})$, opportunities $(\mathrm{O})$, threats $(\mathrm{T})$;

1. Tabulate the strengths and weaknesses, estimate them on a standard scale (e.g., on a scale of 1 to 5 ), and summarise them;

2. Follow a similar process (step 1) for opportunities and threats;

3. Explore the best strategy out of the four: attack from a position of $\mathrm{SO}$, defence from a position of $\mathrm{WO}$, adapt from a position of ST, and try to minimise the effects of a crisis from a position of WT;

4. Assess the PSS by applying the following formula:

$$
\mathrm{PSS}=\frac{\mathrm{SP}+\mathrm{AS}}{2}
$$

where PSS is the coefficient of the probability of strategic success; SP denotes the internal strengths, AS is the attractiveness of the environment, and $0<$ PSS $\leq 1$ and PSS $>0.5 \rightarrow 1$.

The PSS ranges from 0 to 1 ; if the coefficient exceeds 0.5 , then the business is successful [53]. Thus, internal strengths $(\mathrm{S})$ and weaknesses $(\mathrm{W})$ are administered to investigate SP, opportunities $(\mathrm{O})$, and threats (T) for the AS computation. Then, SP and AS can be calculated as follows:

$$
\mathrm{SP}=\frac{\sum \mathrm{S}}{\sum \mathrm{S}+\mathrm{W}}, \mathrm{AS}=\frac{\sum \mathrm{O}}{\sum \mathrm{O}+\mathrm{T}}
$$

\subsubsection{The Wilcoxson Mann-Whitney Rank-sum Test}

We investigate different opinions based on gender, age groups, and types of work. Specifically, we investigate the views of experts on men and women who were aged 30 years and under and 31 years and over. We divide the age group into 30 and under and 31 and above because Euromonitor International [59] finds that people below the age of 30 make up more than half (50.5\%) of the world's population. Similarly, we also divide the experts into two groups based on their work. The professor or teacher, politicians, and government officials are considered to be public workers, and the rest are private workers.

The Wilcoxson Mann-Whitney rank-sum test is used to explore whether both sets of information provided by the two groups are significantly different from each other [60]. More precisely, it is used to 
measure the moods, attitudes, and quality of the respondents. Presenting the mean difference between groups is uninformative in ordinal scale data types, whereas the Mann-Whitney statistic is highly informative. It presents the likelihood that a member of one group will score higher than a member of the other group [60]. Moreover, during the SWOT analysis, we do not use the attributes of the respondents. We aim to observe whether men or women are an important source of human resources for Nepalese agritourism. Thus, we investigate the responses of the experts and test $\mathrm{H}_{2}$ (the role of women in agritourism is important even in a male-dominated society where women are more involved in household activities).

\section{Results and Discussions}

\subsection{IFEM and EFEM Results}

As presented in Table 3, the mean is the average score given to each factor by the experts. The mean value of the strengths shows that 'young and energetic farmers' and 'attractions' rank first and second, respectively. That is, they are strong 'strengths'. Regarding the weaknesses, 'inadequate infrastructure for tourism' and 'human resources do not meet the tourists' standards' have the lowest mean values. That is, these harboured the most weaknesses. The standard deviation is SD, and the Cronbach's alpha shows the consistency and reliability of the variables in the group. A Cronbach's alpha value between 0.70 and 0.90 is recommended as an ideal [61]; we obtain a value within this range. The total IFEM score is 2.93 (Table 3). That is, the village has more strengths than weaknesses for the development of agritourism.

Table 4 reveals the result of the EFEM. Regarding this matrix, we refer to the standard range of Cronbach's alpha values. Based on mean values, the role of 'migrant returnees' and 'gradual increment of international visitors to Nepal' rank first and second in relation to opportunities, respectively. Thus, they harbour better opportunities for agritourism development in the village. Concerning the threats, 'natural disaster' and 'migration of a young generation from agriculture to other sectors' show smaller mean values. That is, they are the most significant threats. Moreover, the total weight score of the EFEM is 2.92, suggesting that the village has more opportunities than threats. Therefore, an attack strategy is better (presented in Table 5) because it is aggressive and offers more opportunities and strengths. Additionally, weaknesses and threats are compared based on minimum values because they are negative contributors.

Table 3. The internal factor estimation matrix (IFEM).

\begin{tabular}{|c|c|c|c|c|c|c|}
\hline Items & Mean & SD & Cronbach Alpha & Weight (W) & Effective Score (E) & Final Score $\left(W^{*} E\right)$ \\
\hline \multicolumn{7}{|l|}{ Strengths } \\
\hline \multicolumn{7}{|l|}{ Tourism attractions } \\
\hline $\begin{array}{l}\text { hills, and a snow-covered } \\
\text { mountain view) }\end{array}$ & 4.45 & 0.80 & 0.77 & 0.13 & 4 & 0.52 \\
\hline $\begin{array}{l}\text { S2: Cultural (traditions, rituals, } \\
\text { and local festivals) }\end{array}$ & 4.13 & 0.83 & 0.78 & 0.13 & 4 & 0.52 \\
\hline $\begin{array}{l}\text { S3: Local products (millet wine, } \\
\text { organic agricultural products) }\end{array}$ & 3.91 & 0.92 & 0.76 & 0.10 & 3 & 0.30 \\
\hline S4: Handicrafts (metal, non-metal) & 3.91 & 0.92 & 0.78 & 0.09 & 3 & 0.27 \\
\hline S5: Young and energetic farmers $※$ & 4.68 & & 0.79 & 0.11 & 4 & 0.44 \\
\hline Male farmers & 4.68 & 0.57 & 0.79 & & & \\
\hline
\end{tabular}


Table 3. Cont.

\begin{tabular}{|c|c|c|c|c|c|c|}
\hline Items & Mean & SD & Cronbach Alpha & Weight (W) & Effective Score (E) & Final Score $\left(W^{*} E\right)$ \\
\hline \multicolumn{7}{|l|}{ Weakness } \\
\hline $\begin{array}{l}\text { W1: Inadequate infrastructure for } \\
\text { tourism }\end{array}$ & 2.77 & 0.86 & 0.77 & 0.12 & 2 & 0.24 \\
\hline $\begin{array}{l}\text { W2: Low education level of } \\
\text { farmers } ※\end{array}$ & 3.25 & & 0.79 & 0.11 & 2 & 0.22 \\
\hline Male farmers & 3.45 & 0.67 & 0.78 & & & \\
\hline Low quality of the male farmers & 3.31 & 1.15 & 0.77 & & & \\
\hline Low quality of the female farmers & 2.90 & 1.32 & 0.77 & & & \\
\hline $\begin{array}{l}\text { W4: Poor quality of local } \\
\text { agricultural products due to } \\
\text { traditional technologies used and } \\
\text { no irrigation facility }\end{array}$ & 3.13 & 1.35 & 0.77 & 0.09 & 2 & 0.18 \\
\hline
\end{tabular}

Source: Authors' August 2017 survey with farmers as respondents $(n=64)$ and authors' January 2019 survey of experts $(n=22)$. Notes: $※$ refers to the male and female average. The data of the first survey are used to define the strengths, weaknesses, opportunities and threats (SWOT).

Table 4. The external factor estimation matrix (EFEM).

\begin{tabular}{|c|c|c|c|c|c|c|}
\hline Items & Mean & SD & Cronbach Alpha & Weight (W) & Effective Score(E) & Final Score $\left(W^{*} E\right)$ \\
\hline \multicolumn{7}{|l|}{ Opportunities } \\
\hline O1: Nearby trekking trails & 3.05 & 1.22 & 0.78 & 0.16 & 4 & 0.64 \\
\hline O2: Migrant returnees $*$ & 4.39 & & 0.80 & 0.12 & 4 & 0.48 \\
\hline Role of men & 4.41 & 0.73 & 0.80 & & & \\
\hline Role of women & 4.36 & 1.04 & 0.79 & & & \\
\hline $\begin{array}{l}\text { O3: Gradual increment of } \\
\text { international visitors in Nepal }\end{array}$ & 3.55 & 1.22 & 0.78 & 0.12 & 4 & 0.48 \\
\hline $\begin{array}{l}\text { O4: Government introduces } \\
\text { policies that support tourism } \\
\text { and agricultural development }\end{array}$ & 3.18 & 0.86 & 0.78 & 0.16 & 4 & 0.64 \\
\hline $\begin{array}{l}\text { O5: Development spirit and } \\
\text { commitments of local } \\
\text { political leader }\end{array}$ & 2.73 & 1.03 & 0.78 & 0.12 & 3 & 0.36 \\
\hline \multicolumn{7}{|l|}{ Threats } \\
\hline $\begin{array}{l}\text { T1: Migration of a young } \\
\text { generation from agriculture } \\
\text { to other sectors } ※\end{array}$ & 2.29 & & 0.84 & 0.10 & 1 & 0.10 \\
\hline Men & 1.90 & 0.99 & 0.79 & & & \\
\hline Women & 2.68 & 0.87 & 0.89 & & & \\
\hline $\begin{array}{l}\text { T2: Potential competition } \\
\text { with established tourism } \\
\text { destination }\end{array}$ & 2.95 & 1.29 & 0.80 & 0.12 & 1 & 0.12 \\
\hline \multirow[t]{2}{*}{$\begin{array}{l}\text { T3: Natural disaster } \\
\text { (landslide, drought) }\end{array}$} & 2.81 & 1.10 & 0.81 & 0.10 & 1 & 0.10 \\
\hline & Total & & & 1.00 & & 2.92 \\
\hline
\end{tabular}

Source: Authors' August 2017 survey of farmers $(n=64)$ and authors' January 2019 survey of experts $(n=22)$.

Notes: $※$ refers to the male and female average. The data of the first survey are used to define the SWOT.

The results of the IFEM and the EFEM suggest that Phikuri village has the potential for agritourism development, which confirms $\mathrm{H}_{1}$. Therefore, we developed strategies for agritourism development and presented them in Table 5. The attract strategies involve utilising internal strengths to make optimal use of external opportunities for the development and promotion of agritourism. The defence strategies involve maximising internal strengths and tackling external threats. Similarly, adaptation strategies involve minimising internal weaknesses and maximising external opportunities. Finally, the crisis strategies involve minimising weaknesses and threats. Greater emphasis should be placed on crisis strategies during agritourism development. Otherwise, the potential for the development of agritourism would reduce. 
Table 5. Strategic action for agritourism development.

\begin{tabular}{|c|c|c|}
\hline Item & Opportunities (+) & Threats (-) \\
\hline & Maxi-maxi strategy/ATTACK & Maxi-mini strategy/ DEFENCE \\
\hline \multirow[t]{2}{*}{ Strengths $(+)$} & $\begin{array}{l}\text { SO1: Introduce a particular itinerary and } \\
\text { package focussing on the trekkers (S1-2, O1) } \\
\text { SO2: Attract migrant returnees and the young } \\
\text { generation by improving the quality of typical } \\
\text { products (S3-4, O2) } \\
\text { SO3: Pay special attention to international } \\
\text { travellers and develop a strategy to attract them } \\
\text { to the village (S1-2, O3) } \\
\text { SO4: Use a government subsidy to increase the } \\
\text { quality of services and the capacity building of } \\
\text { young farmers (S5, O4) } \\
\text { SO5: Adopt the strategy developed by the } \\
\text { political leaders (S1-4, O5) }\end{array}$ & $\begin{array}{l}\text { ST1: Commercialise typical products and } \\
\text { tourist attractions that help draw the } \\
\text { attention of the young generation (S5, T1) } \\
\text { ST2: Conduct a bilateral agreement with the } \\
\text { established tourism destination to increase } \\
\text { the quality of products and upgrade the skills } \\
\text { of the farmers (S3, S5, T2) } \\
\text { ST3: Promote the village from a tourism } \\
\text { perspective (S1-4, T1) }\end{array}$ \\
\hline & Mini-maxi strategy/ ADAPTATION & Mini-mini strategy/CRISIS \\
\hline Weaknesses (-) & $\begin{array}{l}\text { WO1: Develop a good infrastructure network to } \\
\text { connect village and trekking trails (W1, O1) } \\
\text { WO2: Attract more youth and migrant returnees } \\
\text { to the agricultural sector, so that they can easily } \\
\text { teach and transfer their knowledge to their fellow } \\
\text { farmers (W2-3, O2) } \\
\text { WO3: Develop quality local products to meet the } \\
\text { needs and demands of international } \\
\text { visitors (W4, O3) } \\
\text { WO4: Adopt government policy or offer } \\
\text { subsidies to develop the quality of human } \\
\text { resources (W3, O4-5) }\end{array}$ & $\begin{array}{l}\text { WT1: Lack of quality services and } \\
\text { infrastructure are obstacles to the } \\
\text { development of agritourism (W1, T2) } \\
\text { WT2: Poor levels of education and the } \\
\text { changing interests of the younger generation } \\
\text { reduces the potential of agritourism } \\
\text { development (W1, T1) } \\
\text { WT3: Quality assurance and a competitive } \\
\text { environment are some of the challenges faced } \\
\text { by new tourism destinations (W1-4, T2) }\end{array}$ \\
\hline
\end{tabular}

Source: Authors' elaboration based on the IFEM and EFEM. Notes: $\mathrm{S}=$ strengths, $\mathrm{W}=$ weaknesses, $\mathrm{O}=$ opportunities,

$\mathrm{T}=$ threats.

\subsection{Results of the PSS}

The PSS is calculated using the formula from Section 3.3.2. We calculate the average value of each variable based on the responses of each of the four vectors (i.e., the SWOT), and the PSS is calculated as follows:

$$
\begin{aligned}
& \sum \mathrm{S}=21.08, \sum \mathrm{W}=12.26, \sum \mathrm{O}=16.90, \sum \mathrm{T}=8.05 \\
& \mathrm{SP}=\frac{21.08}{21.08+12.55}, \mathrm{SP}=0.63 \\
& \mathrm{AS}=\frac{16.90}{16.90+8.05}, \mathrm{AS}=0.68 \\
& \mathrm{PSS}=\frac{0.63+0.68}{2}, \mathrm{PSS}=0.65
\end{aligned}
$$

The value of the PSS is over 0.5, which suggests that the PSS of agritourism is high in Phikuri village. This result also confirms the first hypothesis.

After understanding the potential that a village has for agritourism development, we use the SWOT defined earlier to develop strategies by applying the IFEM and the EFEM. As mentioned in Section 2.3, four main strategies and 15 sub-strategies are developed and presented in Table 5. Although all are equally important, the crisis strategies are a combination of minus-minus elements. They should be given special attention because they could reduce the possibilities of agritourism development.

\subsection{Results of the Wilcoxson Mann-Whitney Rank-sum Test}

We compare the opinions of the male and female respondents of the second survey on agritourism development (Table 6). We find significantly different opinions concerning natural attractions ( $5 \%$ significant) as a strength, low quality of the female workforce $(10 \%$ significant) as a weakness, the role of migrant returnees (male) from foreign countries (10\% significant) and a young generation (female) (10\% significant) as opportunities, and possible competition with established destinations ( $5 \%$ significant) as a threat to agritourism development. More specifically, women are more concerned 
about natural attractions, the quality of the female workforce, and competition with established destinations. In other words, men and women have significantly different views on the elements of strengths, weaknesses, opportunities, and threats.

The respondents aged 30 and under and 31 and above have significantly different opinions on available handicrafts in the village ( $5 \%$ significant), that is, the strengths; young generations ( $\leq 30$ years) (both male and female) working in agriculture (10\% significant) constitute an opportunity; and male migration from the village ( $1 \%$ significant) is a threat. More specifically, unlike people aged 31 years and above, the young generation believes that male migration is a greater threat to agritourism. Those aged 31 years and above believe that handicrafts and the young generation working in agriculture are strengths and opportunities, respectively.

Table 6. Comparing the different opinions of the respondents based on gender, age, and types of work (the Wilcoxson Mann-Whitney rank-sum test).

\begin{tabular}{|c|c|c|c|c|c|c|c|c|c|}
\hline \multirow{2}{*}{ Items } & \multicolumn{3}{|c|}{ Gender } & \multicolumn{3}{|c|}{ Age } & \multicolumn{3}{|c|}{ Types of Work } \\
\hline & Female & Male & Z-Value & $\leq 30$ & $31 \leq$ & Z-Value & Public & Private & Z-Value \\
\hline \multicolumn{10}{|l|}{ Strengths } \\
\hline Natural attractions & 80.0 & 173.0 & $2.018 * *$ & & & & & & \\
\hline Handicrafts & & & & 147.0 & 106.0 & $2.248^{* *}$ & & & \\
\hline \multicolumn{10}{|l|}{ Weaknesses } \\
\hline Low-quality female workforce & & & & & & & 90.0 & 163.0 & $1.888 *$ \\
\hline Low-quality male workforce & 36.0 & 217.0 & $-1.800 *$ & & & & & & \\
\hline $\begin{array}{l}\text { Poor quality of local agricultural } \\
\text { products due to the use of } \\
\text { traditional technologies and no } \\
\text { irrigation facility }\end{array}$ & & & & & & & 161.5 & 91.5 & $1.882 *$ \\
\hline \multicolumn{10}{|l|}{ Opportunities } \\
\hline Role of migrant returnees (male) & 77.5 & 175.5 & $1.835^{*}$ & & & & & & \\
\hline Young generation (male) & & & & 134.5 & 118.5 & $1.653 *$ & & & \\
\hline Young generation (female) & 36.0 & 217.0 & $-1.800 *$ & 134.5 & 118.5 & $1.653 *$ & & & \\
\hline $\begin{array}{l}\text { Development commitments of } \\
\text { political leaders }\end{array}$ & & & & & & & 152.5 & 100.5 & $-2.625^{* * *}$ \\
\hline Government supportive policy & & & & & & & 148.0 & 105.0 & $-2.278^{* *}$ \\
\hline International tourist arrival ratio & & & & & & & 141.5 & 111.5 & $-1.813 *$ \\
\hline \multicolumn{10}{|l|}{ Threats } \\
\hline Possible competition & 81.5 & 171.5 & $2.126^{* *}$ & & & & & & \\
\hline Labour migration (male) & & & & 73.5 & 179.5 & $-2.918^{* * *}$ & & & \\
\hline \multicolumn{10}{|l|}{ Women's role in agritourism } \\
\hline Marketing of agritourism & 32.0 & 221.0 & $-2.097 * *$ & & & & & & \\
\hline Guiding tourists around & & & & 140.0 & 113.0 & 1.739 * & & & \\
\hline Selling of goods & & & & & & & 75.5 & 177.5 & $2.706^{* * *}$ \\
\hline
\end{tabular}

The comparison between public workers and private workers also demonstrates significant differences in opinion regarding the low quality of the female workforce ( $10 \%$ significant), the traditional technologies used for agriculture, and the lack of irrigation facilities ( $10 \%$ significant) as weaknesses. Further, the vision and commitments of political leaders ( $5 \%$ significant), government support to the farmers (10\% significant), and international visitors arriving in the country (10\% significant) are opportunities for agritourism development. Clearly, private, and public workers differ in terms of technologies used in agriculture, the commitment of political leaders, a supportive government policy in relation to tourism, and agricultural development. Public workers are more concerned with the lower quality of the female workforce in the village. Thus, we can state that the private sector has positive expectations in relation to political leaders and supportive government policies.

We also investigate the possible role of women in agritourism because women are an important workforce. We explore the supportive activities of women for agritourism, such as marketing agritourism at the 5\% significance level (based on gender), guiding tourists around at the $10 \%$ significance level (based on the age group), and selling of goods at the $1 \%$ significance (based on the type of work) level. Out of all of them, the selling of goods is a strategically suitable job for 
women because the selling of goods in agritourism does not require advanced skills and knowledge as compared to other job types. However, it creates an income source for women who have been economically dependent on men. We also test some other supportive jobs done by women, such as cleaning and cooking. However, these factors are not significantly different from each other in the groups. These results support $\mathrm{H}_{2}$, confirming the important role of women in establishing and developing agritourism.

\section{Conclusion and Implications}

Based on data collection in an agrarian village in rural Nepal, namely, Phikuri village, we first defined the SWOT of agritourism development. We applied three different statistical tests to explore the possibilities of agritourism development, and we tested two hypotheses. We also developed SWOT strategies for agritourism in the village and investigated the role of women as a human resource. The authors believe that the guidelines presented herein will help develop sustainable agritourism in rural villages. The main findings are summarised as follows.

We conducted a SWOT analysis to determine agritourism development strategies in a region with no previous agritourism projects. Moreover, we explored various potentials by using the IFEM and EFEM analysis. We found that Phikuri village has immense potential for agritourism development. The village has young and energetic farmers, numerous tourist attractions, a population of migrant returnees, and an increasing number of international tourists, which can be described as positive factors. However, inadequate infrastructure and the low quality of human resources are negative contributions. The statistical results suggest that the internal environment is more favourable than the external environment for agritourism development. This result confirms our first hypothesis, that is, an agrarian village has the potential for agritourism development. As a generalisation, we can claim that a typical agrarian village in a developing economy would also have similar potential. Further, the PSS results indicate that the environment for agritourism development in the village is relatively favourable. This result is consistent with the result of the IFEM (Table 3) and EFEM (Table 4). Thus, rural agritourism favours development.

The main contribution of our study is that we empirically determined a strategy for agritourism development in a village. We developed four strategies-attack, defence, adaptation, and crisis-as well as 15 sub-strategies. We find that the crisis strategy (the combination of weaknesses and threats, or the mini-mini strategy) deserves special attention because of its potential to weaken the probability of the success of agritourism. The conclusion confirmed what is usually said about the SWOT analysis: it is a practical, scientific, and objective methodology for the clarification of strategic components.

We compared the opinions of three different groups based on age, gender, and type of employment. We found significantly different opinions between men and women, people aged 30 and under and 31 and above, and public and private workers. More specifically, women are more concerned about natural resources and the quality of the female workforce in agritourism development. Respondents aged 30 and under, unlike those aged 31 and above, value the importance of the young generation and handicrafts for agritourism development. Similarly, those aged 31 and above believe that the migration of the young generation from agriculture to other sectors is a threat to agritourism development. Private workers regard government activities and the vision of local political leaders as favourable. Thus, if government policy is supportive and political leaders have a vision for local development, then private workers are ready to cooperate with the current government policy. However, a complaint from the private sector is that agricultural technologies are not sound, indicating the need for upgrading and improving farming technologies and irrigation facilities at the village level.

The second hypothesis $\left(\mathrm{H}_{2}\right)$ states that women have a critical role in agritourism despite living in a male-dominated society and being more involved in household activities. Our results support this hypothesis. We found that guiding tourists, selling goods, and marketing agritourism are vital roles 
that women occupy. Among them, the sale of farm products is the most significant at the $1 \%$ level. That is, such work is the most suitable for women in agritourism in the current context of Nepal. Thus, despite male domination, agritourism development is beginning to create opportunities for gender equality. Our conclusion is consistent with the findings of studies by Duffy et al. [12], Ohe [13], Movono and Dahles [44], Kulekci et al. [40], Akpinar et al. [41], and Tucker and Boonabaana [42].

Public workers and women state that the low quality of the female workforce in agritourism is a great challenge. By using the government's supportive policies and participating in the development vision of political leaders, the capacity of the workforce, especially that of women, can be upgraded to higher standards. Different awareness campaigns and educational training should be launched to promote farming skills. Notably, two different age groups in our study had significantly different opinions on handicrafts. Thus, skill development centres for typical products is necessary. Migrant returnees and the young generation were also found to be crucial for agritourism. Hence, the government should offer more support to these groups with respect to agritourism ventures.

\section{Limitations and Future Studies}

We explored the potential of agritourism and developed SWOT strategies thereof in Nepal's Phikuri village, which has no established agritourism sector. However, this study is only a statistical case study of a small village with a limited number of well-educated respondents. Our survey results are consistent with the results of previous studies [21,22]. However, these results should be further confirmed with larger sample sizes collected through in-depth interviews with farmers in other rural villages as well.

The SWOT analysis cannot deal with factors other than investigating potential and developing strategies, although it can be used as a component of planning. The viability of the SWOT analysis, and the step-by-step planning of agritourism through a multidisciplinary analysis, as well as a SOAR analysis, should be examined in future studies. This would ensure the full potential of agritourism and the implementation of strategies in an agrarian village.

Author Contributions: K.B. contributed to the methodology, resources, data visualisation, and writing; Y.O. conceptualised the study and engaged in the acquisition of funding and supervision; A.C. also conceptualised and supervised the study. All authors have read and agree to the published version of the manuscript.

Funding: This research was funded by the Tojo Alumni Association of the Faculty of Horticulture, Chiba University \#1 under a Research Grant in 2019; Chiba University SEEDS Fund \#2 Chiba University Open Recruitment for International Exchange Program 2019; Japan Society for the Promotion of Science \#3 under Grant-in Aid for Scientific Research no. 18H03965 and Grant-in Aid for JSPS Fellows.

Conflicts of Interest: The authors declare no conflict of interest.

Condolence: To the authors' regret, A.C. unexpectedly passed away at the end of April 2020. The author had a long friendship of 27 years with Y.O. and five years with K.B. The remaining authors express their deepest condolences and gratitude.

\section{References}

1. Bhatta, K.; Itagaki, K.; Ohe, Y. Determinant factors of farmers' willingness to start agritourism in rural Nepal. Open Agric. 2019, 4, 431-445. [CrossRef]

2. Malkanthi, S.H.P.; Routry, J.K. Potential of agritourism development: Evidence from Sri Lanka. J. Agric. Sci. 2011, 6, 45-58. [CrossRef]

3. Ohe, Y. Community-based Rural Tourism and Entrepreneurship: A Microeconomic Approach; Springer: Berlin/Heidelberg, Germany, 2020.

4. Nickols, F. Strategy: Definitions \& Meanings. Distance Consult. 2012, 200, 2-10.

5. Kuehn, D.; Hilchey, D.; Ververs, D.; Dunn, K.L.; Lehman, P. Considerations for Agritourism Development; Oswego: New York, NY, USA, 1998.

6. George, H.; Rilla, E. Marketing Strategies for Agritourism Operations, University of California, Agriculture and Natural Resources. Available online: https://anrcatalog.ucanr.edu/pdf/8444.pdf (accessed on 8 August 2019). 
7. Roth, M.; Ochterski, J. Getting Started with Agritourism; The University of Vermont: Burlington, Vermont, 2016.

8. Telfer, D.J. Taste of Niagara: Building strategic alliances between tourism and agriculture. Int. J. Hosp. Tour. Adm. 2000, 1, 71-88. [CrossRef]

9. Embacher, H. Marketing for Agritourism in Austria: Strategy and realisation in a highly developed tourist destination. J. Sustain. Tour. 1994, 2, 61-76. [CrossRef]

10. Carra, G.; Mariani, M.; Radic, I.; Peri, I. Participatory strategy analysis: Thes case of wine tourism business. Agric. Agric. Sci. Procedia 2016, 8, 706-712. [CrossRef]

11. Indiana State Department of Agriculture. Biennial Budget Transmittal Letter FY $2014-2015$. Available online: https://www.in.gov/sba/files/BC_Hearing_2012_036_ISDA_Agency_Overview.pdf (accessed on 7 November 2019).

12. Duffy, L.N.; Kline, C.; Swanson, J.R.; Best, M.; McKinnon, H. Community development through agroecotourism in Cuba: An application of the community capitals framework. J. Ecotourism 2017, 16, 203-221. [CrossRef]

13. Ohe, Y. Measuring labor productivity and market viability of rural tourism activities in Japan. Res. Top. Agric. Appl. Econ. 2011, 2, 155-167.

14. Ohe, Y. Community-based tourism in super ageing Japan: Challenges and evolution. Rev. Anais Bras. Est. Tur/ABET Juiz Fora 2016, 6, 28-41.

15. Ohe, Y. Educational tourism in agriculture and identity of farm successors. Tour. Econ. 2018, 24, 167-184. [CrossRef]

16. Barbieri, C. Assessing the sustainability of agritourism in the US: A comparison between agritourism and other farms entrepreneurial venture. J. Sustain. Tour. 2013, 21, 252-270. [CrossRef]

17. Mondal, S.H. SWOT analysis and strategies to develop sustainable tourism in Bangladesh. UTMS J. Econ. 2017, 8, 159-267.

18. Reihanian, A.; Mahamood, N.Z.B.; Kahrom, E.; Hin, T.W. Sustainable tourism development strategy by SWOT analysis: Boujagh National park, Iran. Tour. Manag. Perspect. 2012, 4, 223-228. [CrossRef]

19. Celik, N. Strategy Making with Quantified SWOT Approach: A Case Analysis on Tourism Industry in Black Sea Region of Turkey. Available online: http://lexetscientia.univnt.ro/download/168_lesij_es_XIV_2007_art_ 12.pdf (accessed on 12 December 2019).

20. Wang, H.; Li, C.; Zheng, Y. Space expression of industry status using GIS and SWOT analysis. Wuhan Univ. J. Nat. Sci. 2015, 20, 445-454. [CrossRef]

21. Pandey, H.; Pandey, R. Socio-economic development through agro-tourism: A case study of Bhaktapur, Nepal. J. Agric. Environ. 2011, 12, 59-66. [CrossRef]

22. Shrestha, U.; Dongol, D.R.; Pandey, R.J.; Bhattarai, I. Study of the purpose of agritourism development: A case study of Kirtipur municipality. Agric. Dev. J. 2011, 8, 109-116.

23. Kurnianto, B.T.; Sugiyanto, K.H.; Sukesi, K. Agrotourism development strategies based on institutional at Wonorejo Reservoir, Tulungagung, East Java, Indonesia. J. Environ. Earth Sci. 2013, 3, 11-17.

24. Phelan, C.; Sharpley, R. Exploring agritourism entrepreneurship in the UK. Tour. Plan. Dev. 2011, 8, 121-136. [CrossRef]

25. Nepal Government. Tourism Vision 2020. Available online: http://old.tourism.gov.np/downloadfile/ 1Tourism-Vision-2020-Final2.pdf (accessed on 29 November 2019).

26. Bhatta, K.; Ohe, Y. Farmers' willingness to establish community-based agritourism: Evidence from Phikuri village, Nepal. Int. J. Tour. Sci. 2019, 19, 128-144. [CrossRef]

27. Lane, B.; Kastenholz, E. Rural tourism: The evolution of practice and research approaches-towards a new generation concept? J. Sustain. Tour. 2015, 23, 1133-1135. [CrossRef]

28. Adams, B.B. The New Agritourism; New World Publishing: Novato, CA, USA, 2008.

29. Ohe, Y.; Ciani, A. Accessing demand characteristics of agritourism in Italy. Tour. Hosp. Manag. 2012, 18, 281-296.

30. Hegarty, C.; Przezborska, L. Rural and agri-tourism as a tool for reorganising rural areas and old and new member states- a comparison study of Ireland and Poland. Int. J. Tour. Res. 2005, 7, 63-77. [CrossRef]

31. Kastenholz, E.; Santos, E.; de, O. The evolution of profile and motivations of agro-tourists in Rio Grande do Sul/Brasil. PASOS. Rev. Tur. Patrmonio Cult. 2014, 12, 597-609. [CrossRef]

32. Darau, A.P.; Cirneliu, M.; Brad, M.L.; Avram, E. The concept of rural tourism and agritourism. Vasile Goldis West. Univ. Arad 2010, 5, 39-42. 
33. Ohe, Y. Impact of rural tourism operated by retiree farmers on multifunctionality: Evidence from Chiba, Japan. Asia Pac. J. Tour. Res. 2008, 13, 343-356. [CrossRef]

34. Carpio, E.C.; Wohlgenant, M.K.; Boonsaeng, T. The demand for agritourism in the United States. J. Agric. Resour. Econ. 2008, 33, 245-269.

35. Ohe, Y. From product-out to market-in rural tourism. HortResearch 2019, 73, 8-9.

36. McGehee, N.G.; Kim, K. Motivation for agri-tourism entrepreneurship. J. Travel Res. 2004, 43, 161-170. [CrossRef]

37. Eurac Research. Outcome Statement: 1st World Congress on Agritourism 2018. Available online: https://agritourism.eurac.edu/wac/wac2018/WAC_2018_Outcome\%20Statement_A4.pdf (accessed on 12 February 2020).

38. International Finance Corporation. Women and Tourism: Designing for Inclusion; World Bank Group: Washington, DC, USA, 2017.

39. Carvalho, I.; Costa, C.; Lykke, N.; Torres, A.; Wahl, A. Women at the top of tourism organisations: Views from the glass roof. J. Hum. Resour. Hosp. Tour. 2018, 17, 397-422. [CrossRef]

40. Kulekci, E.A.; Sezen, I.; Bulut, Y. The role of women in rural tourism. The sample of Gaziler Village (Bardez), Erzurum, Turkey. J. Food Environ. 2012, 10, 1314-1319.

41. Akpinar, N.; Talay, I.; Ceylan, C.; Gunduz, S. Rural women and agrotourism in the context of sustainable rural development: A case study from Turkey. Environ. Dev. Sustain. 2005, 6, 473-486. [CrossRef]

42. Tucker, H.; Boonabaana, B. A critical analysis of tourism, gender and poverty reduction. J. Sustain. Tour. 2012, 20, 437-455. [CrossRef]

43. Anuja, B.; Cooper, M. Women's Role in Indian Rural Tourism: Towards a Social-Infrastructure Model for Rural Development. Master's Thesis, Ritsumeikan Asia Pacific University, Beppu, Japan, 2004.

44. Movono, A.; Dahles, H. Female empowerment and tourism: A focus on business in a Fijian village. Asia Pac. J. Tour. Res. 2017, 17, 681-692. [CrossRef]

45. Kastenholz, E.; Carneiro, M.J. Rural tourist experiences. In Book Meeting Challenges for Rural Tourism through Co-creation of Sustainable Tourist Experiences; Kastenholz, E., Carneiro, M.J., Eusebio, C., Figueiredo, E., Eds.; Cambridge Scholars: Cambridge, UK, 2016; pp. 21-38.

46. Poonia, A. Applications of remote sensing and GIS in tourism potential evaluation. Int. J. Remote Sens. GIS 2013, 2, 11-20.

47. Jimura, T. The impact of world heritage site designation on local communities: A case study of Ogimachi, Shirakawa-mura, Japan. Tour. Manag. 2011, 32, 288-296. [CrossRef]

48. Stavros, J.M. The Generative nature of SOAR: Applications, results and the new SOAR profile. AI Pract. Int. J. Appreciative Inq. 2013, 15, 7-30. [CrossRef]

49. Rivero, M.S.; Martín, J.M.S.; Gallego, J.I.R. Methodological approach for assessing the potential of a rural tourism destination: An application in the province of Caceres (Spain). Curr. Issues Tour. 2016, 19, 1084-1102. [CrossRef]

50. Morachat, C. A Study of Destination Attractiveness through Tourists' Perspectives: A Focus on Chiang Mai, Thailand. Ph.D. Thesis, Edith Cowan University, Joondalup, Australia, 2003.

51. Fernando, S.; Bandara, J.S.; Smith, C. Regaining Missed Opportunities: The Role of Tourism in Post-war Development in Sri Lanka. Asia Pac. J. Tour. Res. 2013, 18, 685-711. [CrossRef]

52. Rahmani, S.M.; Hajari, B.; Karimian, T.; Hajilo, M. Rural tourism development strategies using SWOT analysis: Case study. Life Sci. J. 2013, 10, 395-403.

53. Goranczewski, B.; Puciato, D. Swot analysis in the formulation of tourism development strategies for destinations. Tourism 2010, 20, 45-53. [CrossRef]

54. Khayyati, E.; Nourani, S. Strategic Planning for Tourism Development Using S.W.O.T Model Case Study: Borjlou Tourist village in Ardebil. MAGNT Res. Rep. 2014, 2, 12-21.

55. Nepal Government, Ministry of Finance [MOF]. Economic Survey 2074/75. Available online: http://mof.gov. np/uploads/document/file/economic-survey.pdf (accessed on 8 October 2019).

56. World Bank. The World Bank in Nepal. Available online: https://www.worldbank.org/en/country/nepal (accessed on 8 January 2020).

57. Nepal Tourism Board [NTB]. Nepal Tourism Statistics 2018; Nepal Tourism Board: Kathmandu, Nepala, 2019.

58. Nepal Government Census. National Population Housing Census; Nepal Government Census: Kathmandu, Nepal, 2011. 
59. Euromonitor International. Special Report: The World's Youngest Populations. Available online: https: //blog.euromonitor.com/special-report-the-worlds-youngest-populations/ (accessed on 10 November 2019).

60. Conroy, R.M. What hypotheses do "nonparametric" two-group tests actually test? Stata J. 2012, 12, 182-190. [CrossRef]

61. Tavakot, M.; Dennick, R. Making sense of Cronbach's alpha. Int. J. Med Educ. 2011, 2, 53-55. [CrossRef] [PubMed]

(C) 2020 by the authors. Licensee MDPI, Basel, Switzerland. This article is an open access article distributed under the terms and conditions of the Creative Commons Attribution (CC BY) license (http://creativecommons.org/licenses/by/4.0/). 